\title{
腎切石術における術後血尿期間の検討
}

$\begin{array}{ccccc} & \text { 福 } & \text { 岡 } & & \text { 洋 } \\ \text { 横浜市立大学医学部泌尿器科学教室 } & \text { 村 } & \text { 山 } & \text { 鉄 } & \text { 郎 } \\ \text { (主任: 高井修道教授) } & \text { 小 } & \text { 川 } & \text { 勝 } & \text { 明 } \\ & \text { 高 } & \text { 井 } & \text { 修 } & \text { 道 }\end{array}$

\section{CLINICAL OBSERVATIONS ON DURATION OF HEMATURIA FOLLOWING NEPHROLITHOTOMY}

\author{
Hiroshi Fukuoka, Tetsuo Murayama, Katsuaki Ogawa and Shudo Takai \\ Department of Urology, Yokohama City University School of Medicine, Yokohama
}

(Director: Prof. S. Takai)

The relationship between duration of gross hematuria and factors appearing to affect such duration was studied on 12 cases of nephrolithotomy utilizing one- layer interrupted suture of renal parenchyma (Dr. H. Taguchi) and the following results were obtained.

1. The average duration of gross hematuria as observed from postoperative day 0 to day 14 was $4.7 \pm 4.2$ days.

2. No correlation was observed between the duration of postoperative gross hematuria on the one hand and the patient's age, ischemic time and length of renal parenchymal incision.

3. - Renal biopsy during surgery indicated a significantly longer duration of postoperative hematuria among patients with chronic pyelonephritis as compared with other patients.

4. Although the complication of chronic pyelonephritis did not prevent us from carrying out nephrolithotomy, it is suggested that this complication may be one of the factors prolonging duration of postoperative hematuria. Rigorous care must be taken to completely close the incision and to exactly suture the renal pelvic mucosa if postoperative hematuria in one-layer suture of renal parenchyma is to be reduced to a minimum.

\section{緒言}

珊瑚状結石扣よびこれに類する腎結石の観血的治療に 際して全ての結石が広範囲腎酉切石術で摘出されること が理想ではあるが，な和腎切石術が適応となる場合も少 なくない。腎切石術では二次出血や術後腎機能障害が問 題となり危険性の高い手術と考えられてきたが，1967年 田口の考案した腎実質一層縫合法(1) 6) を行ならことでこ れらの危険性は十分に克服されるよらになつてきた.

しかし実質を切開し縫合するからには, 術後の血尿は 色々の程度の差こそあれ必然のことと考兄られている。 腎実質一層縫合法による腎切石術では術後肉眼的血尿が 全くみられないこともある反面, 二次出血の範盽には入 らないが 2 週間近く血尿が持続することもある. 術後血 尿は皆無かあつても極く短期間であることが理想であ
る.

このため術後血尿期間とこれに影響を与えると思われ た因子を検討し，またその対策について若干の考察を加 えたので報告する。

\section{対象と方法}

1977年 6 月から1978年10月までの 1 年 5 カ月間に, 横 浜市立大学医学部病院泌尿器科で実施した腎実質一層縫 合による腎切石術12例を対象とした。性別は男子 8 例， 女子 4 例. 年齡は 29 歳から 58 歳, 平均 46.1 歳であり, 各 症例の腎孟像と結石の関係を第 1 図に示す.

手術術式は田口が考案した腎実質一層縫合法で行なつ た。腎茎部をゴム管付腸鉗子で遮断，腎実質を外凸縁か らやや後方で鋭的に緃切開する. 全ての腎杯を直視下で 観察することを原則とし結石を摘出する．実質縫合は 
第 1 因 術前腎孟像と結石の関係

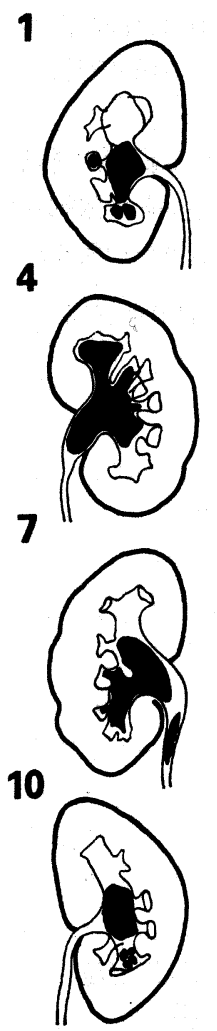

2

5

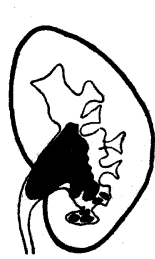

8
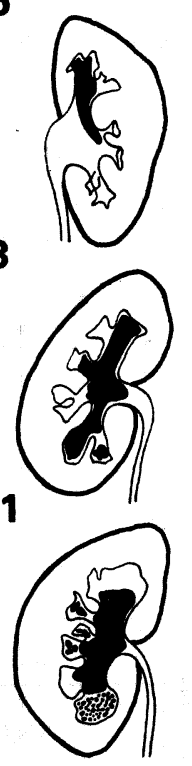

3

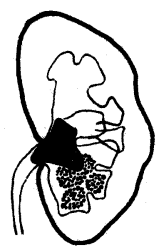

6

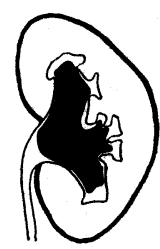

9

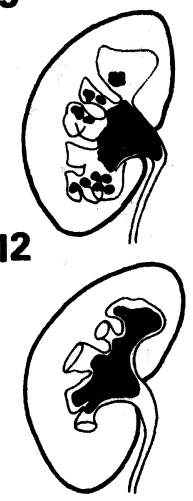

2ー0 プレーンカットグートを腎被膜から腎盂粘膜まで 一層に楕円を描くよう切開縁から $1.0 \mathrm{~cm}$ 以内の範囲で 通し，縫合の間隔は約 $1.5 \mathrm{~cm}$ とする. カットグートを 結禁した後，腎血行を再開する，血流再開による実質の 膨張が縫合糸を支持とする創面への圧迫力となり止血が 達成される.カットグートの結紮部の直下をゆるみ防止 のため綟系で結禁して扰く.

12例の手術時間，術中血行遮断時間の平均はそれぞれ 2 時間 7 分, 26分であり, 術中出血量の平均は $336 \mathrm{cc}$,

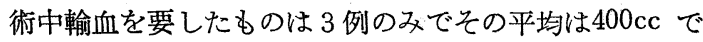
あつた。このほか腎実質切開長，術後肉眼的血尿期間， 腎生検所見の要約を第 1 表に示す。

術後経過はいずれも順調であり，術後腎機能の回復も 良好であつた. 術後肉眼的血尿は全く認めなかつたもの から 2 週間続いたものまであつたが，血尿期間に関連す ると予測された患者年秢, 腎実質切開長, 術中血流遮断 時間，腎生検所見との関係について検討した。

\section{結 果}

術後肉眼的血尿期間は 0 から14日に分布し平均 $4.7 \pm$ 4.2 日であり，顕微鏡的血尿はその後拉よそ 1 週間で 消 失した。

1）患者年齢と血尿期間

患者年秢は 29 歳から 58 歳に 分布し 平均 46.1 歳であつ

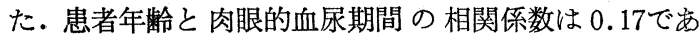
$\eta, \mathrm{t}$ 検定により有意の相関関係はなかつた。したがつ

第 1 表 横浜市大病院泌尿器科における腎実質一層縫合症例（1977．6～1978．10）

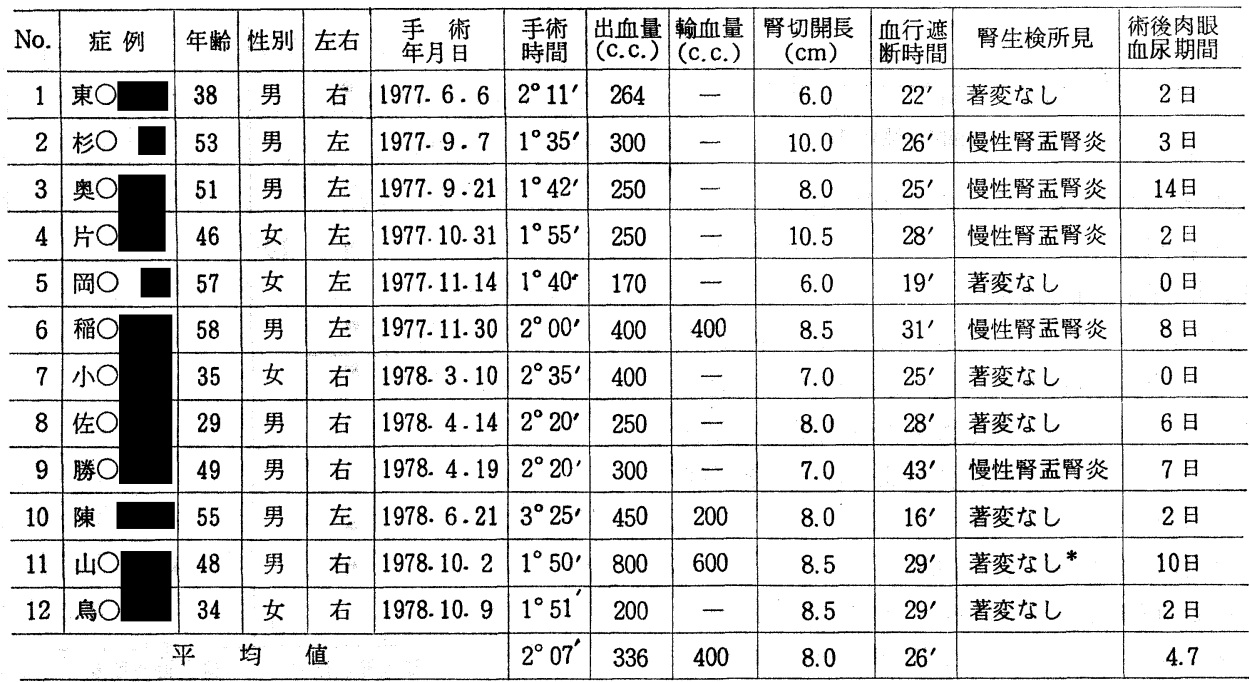

* 残結石が尿管に陥入し，術後著明な急性腎孟腎炎を併発したが結石は自排した. 
第 2 図 患者年齢と肉眼血尿期間

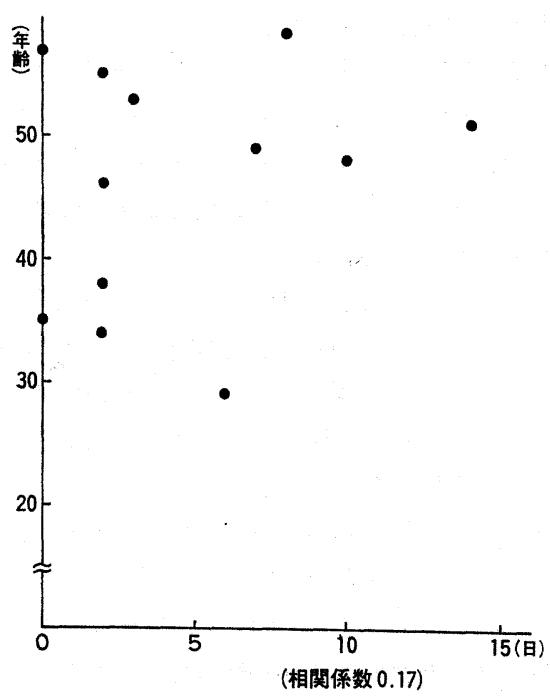

第 3 図 腎実質切開長と肉眼血尿期間

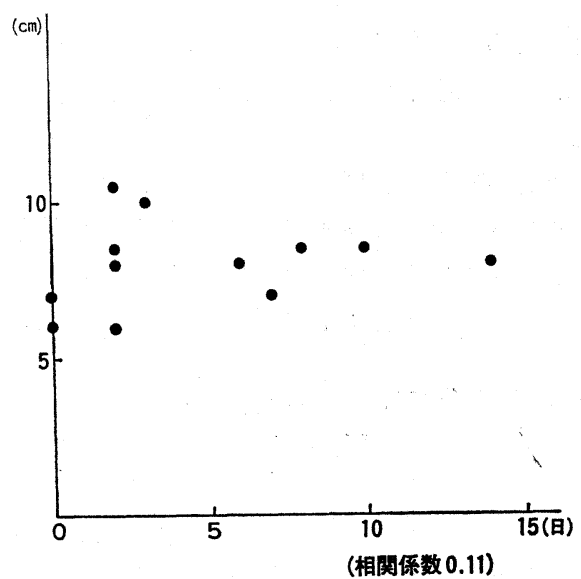

て今回の成績からは高年龄になるほど血尿が持続すると は云えない(第 2 図).

2）腎実質切開長と血尿期間

腎実質切開長は $6.0 \mathrm{~cm}$ から $10.5 \mathrm{~cm}$ に分布し平均 8.0 $\mathrm{cm}$ であつた。腎実質切開長と肉眼的血尿期間の相関係 数は0.11であり, $\mathrm{t}$ 検定により有意の相関関係はみられ なかつた.このことから実質切開長が長くなるほど血尿 が持続するとは云えない(第 3 図).

3）術中腎血流遮断時間と血尿期間

術中血流遮断時間は16分から43分に分布し平均26分で あつた．5例に術中ポータブルX線撮影を行ない残結石 は2 例にみられた。腎血流遮断時間と肉眼的血尿期間の
相関係数は0.36であり， $\mathrm{t}$ 検定により有意の相関関係は みられなかつた。このことから術中腎血流遮断時間が長 くなる注ど血尿が持続するとは云えない(第 4 図).

4）腎生検所見と血尿期間

腎実質切開部の中央より生検を行ない組織学的所見を 検討した。実質の細胞浸潤，線維化，萎縮，尿細管拡 張，糸球体硝子化など何らかの慢性腎盎腎炎の所見がみ

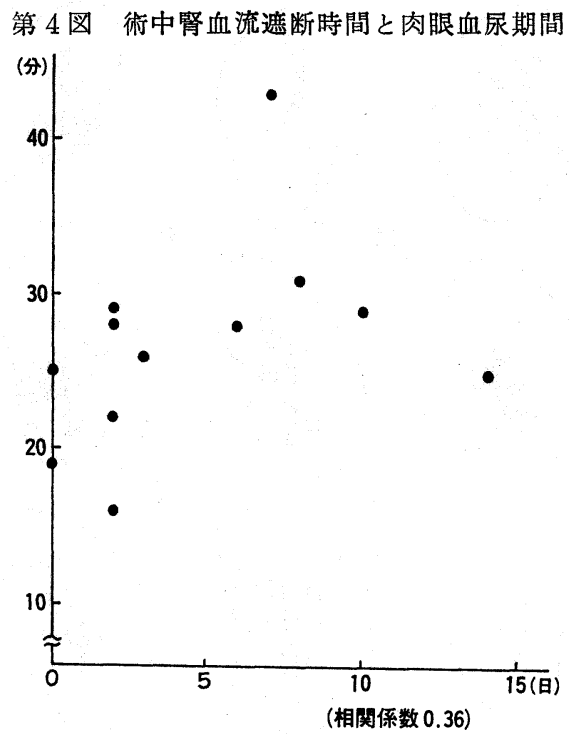

第 5 図 腎生検所見と肉眼血尿期間

(日)

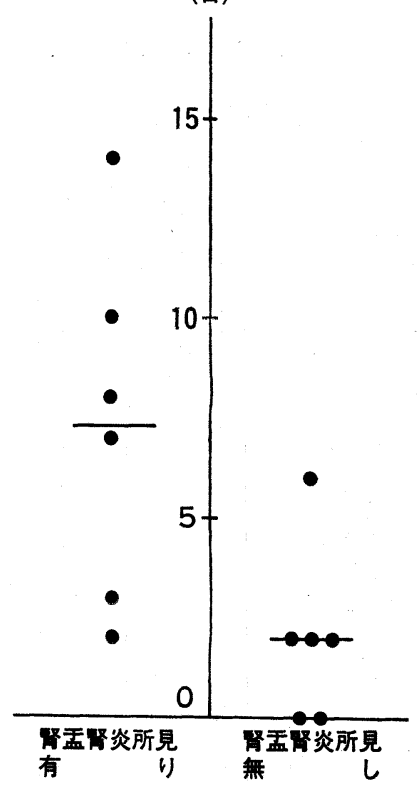


られたものが 5 例 $(41.7 \%)$ ，このよらな所見がみられ ないものが 7 例 $(58.3 \%)$ であつた。この 2 群に拈ける 血尿期間を検討したが，組織像で異常のなかつた症例 11 では術後小さな残結石が尿管に陥入し著明な急性腎孟腎 炎を併発したため腎盂腎炎群に算入した。な扢この小結 石は術後13日目に自然排石し急性腎盂腎炎も急速に治瘉 した。

腎盂腎炎群での血尿期間は平均 7 ・3 日，腎盂腎炎を 認めなからた群での平均は2.0日であり, この両群には 推計上の有意差 $(\mathrm{p}<0.05)$ がみられた（第 5 図）.

\section{症 例}

術後肉眼的血尿期間と腎生検像でそれぞれ代表的な所 見を示した 2 症例の概略を述べる.

症例 3 ．奥○— 51歳，男子．1977年 1 月頃から間 歇的左背部痛，肉眼的血尿が出現した。1977年 1 月29日 横浜市立大学病院泌尿器科を受診し左腎結石症の診断を うけ，1977年 8 月 12 日入院した。 入院時両側腎を触知せ ず左腎部に軽度圧痛があつた。尿所見は蛋白 $(+)$, 沈 渣では白血球多数/毎視野, 赤血球 $2 \sim 3$ /毎視野, 尿培養 Pseudomonas aerug. $10^{5}$ 個/cc 以上. BUN $17 \mathrm{mg} / \mathrm{dl}$, 血 清クレアチニン $1.2 \mathrm{mg} / \mathrm{dl}$. 電解質, 肝機能正常範囲内.

PSP テスト 15 分値10\%，120分值 $45 \%$. フィシュバーグ 濃縮テスト最高 $1,020.24$ 時間内因性クレアチニンクリ アランス $80.01 /$ day. 腎膀脱部単純撮影で左腎部に三角型 の超拇指頭大の結石および無数の砂状結石の集合陰影を 認めた（第 6 図，A）．IVP で右腎機能，腎孟像に異常 を認めず，左腎孟像はUPJ を塞ぐ結石のため全ての腎 杯が中等度に拡張していた（第 6 図，B）．レノグラム では右腎は標準型, 左腎は水腎型を示した。左腎動脈は 2 本存在していたが，広範な支配領域を有する動脈の選 択的撮影で腎内動脈の走行が粗となり, 葉間動脈の軽度 蛇行, 細少化がみられ水腎症と慢性腎孟腎炎の变化が合 併していた（第6図，C).

1977年 9 月21日左腎切石術を施行した. 摘出結石は総 重量 $10.7 \mathrm{~g}$, 赤外線分光分析に上る結石成分は蓚酸カル シウムであつた(第 6 図，D). 術中の腎生検所見は間質 の細胞浸潤括よび軽度の線維化, 一部の糸球体の萎縮が 又られ局所的な慢性腎盂腎炎と診断した（第 6 図，F）。

術後肉眼的血尿は 14 日目飞消失し 経過は良好であつ た。術後単純撮影で残結石を認めず，IVP による腎機 能は良好で腎盂像は腎杯の拡張が著明に改善されていた (第 6 図，E). しかしレノグラムでは左の水腎型は不変 であつた。
症例12.鳥○，34歳，女子. 1978年 5 月末頃から 時々右側腹部痛怙よび肉眼的血尿が出現するようになつ た. 1978年 6 月 15 日横浜市立大学病院泌尿器科を受診し 右腎結石症の診断をうけ，1978年 9 月14日入院した。 入院時両側腎を触知せず圧痛もなかつた。尿所見は蛋白 $(+)$. 沈渣では白血球多数/毎視野, 赤血球多数 $/$ 毎視 野, 尿培養 Proteus mirabilis $10^{5}$ 個/cc 以上. BUN 11 $\mathrm{mg} / \mathrm{dl}$, 血清クレアチニン $0.8 \mathrm{mg} / \mathrm{dl}$. 電解質, 肝機能正常 範囲内. PSP テスト15分值30\%，120分値70\%.フィシ ュバーグ濃縮テスト最高 1,024. 24時間クレアチニンク リアランス $140 l /$ day. 腎膀胱部単純撮影で右腎部に珊瑚 状結石陰影を認めた（第 7 図，A）．IVP で左腎機能, 腎孟像に異常を認めず，右腎盂像は軽度の腎杯拡張を示 した（第 7 図，B）、レノグラムで左腎は標準型，右腎 は遅延型を示した. 右選択的腎動脈撮影で腎内動脈の走 行や腎実質に著変を認めなかつた（第 7 図，C）.

1978年10月 9 日右腎切石術を施行した. 摘出結石の重 量は $8.5 \mathrm{~g}$. 赤外線分光分析による結石成分はリン酸マグ ネシウムアンモニア捄よび少量の蓚酸カルシウムであつ た（第 7 図，D）．術中の腎生検所見は特記すべき異常 を認めなかつた（第7図，F）。

術後肉眼的血尿は 2 日間のみであり経過良好であつ た. 術後単純撮影で残結石を認めず，IVP で右腎機能 は良好で腎盂像は略正常之考兄られた（第 7 図，E）。 またレノグラムも両側標準型を示した。

腎実質一層縫合法は1967年田口が独自に考案し，この 方法による腎切石術の臨床経験で安全性も十分確かめら れ良好な結果を得ている ${ }^{1) ~ 6) . ~}$

腎実質一層縫合法によると縫合が簡単なため手術操作 が短時間に終了し, 術中の腎血流遮断時間の短縮がはか られ15分程度に扣さえることも可能である。また実質縫 合は必要最少限であるため縫合糸による腎主要血管の緊 縛は生ぜず，このため広範な実質壊死やそれに引き䌇く 二次出血も生じない.

この方法による珊瑚状結石に対する腎切石術後の腎機 能の変動について石塚》は腎クリアランス法で一過性の 低下を認めるが術後 2 週以内に術前值に復することを観 察し, 血流遮断時間の短いことが術後腎機能への影響を

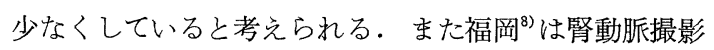
による術前, 術後の腎血管像を比較検討乙術後葉間動脈 レベル以下の動脈中断が平均 $4 \cdot 7$ カ所に出現し, この ための実質硬塞はネフログラム面積についてみると平均 
第 6 図 症例 3，51歳，男子（術後血尿期間14日）
A：腎部単純撮影
B : 術前 IVP
$\mathrm{C}:$ 術前腎動脈撮影
$\mathrm{D} ：$ 摘出結石
$\mathrm{E} ：$ 術後 IVP
F：腎生検所見 $($ H.E. 染色 $\times 40)$

A

B

C
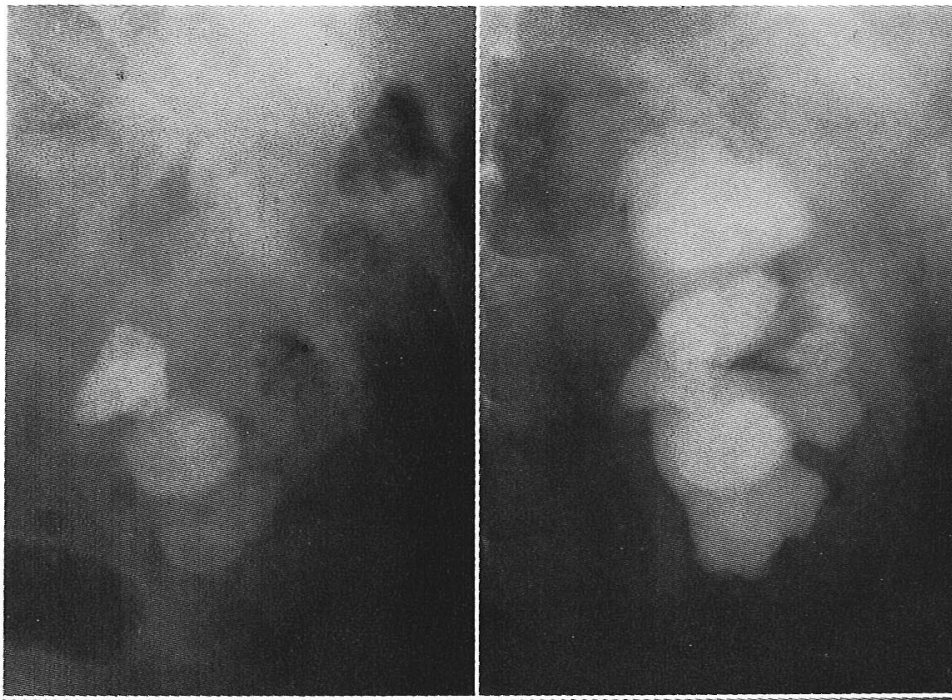

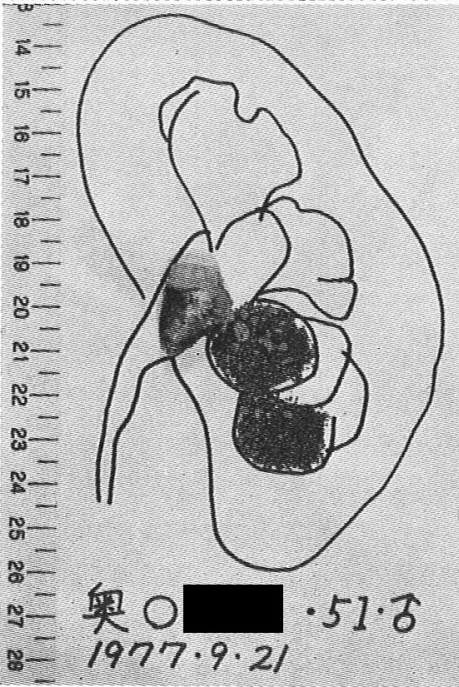

D

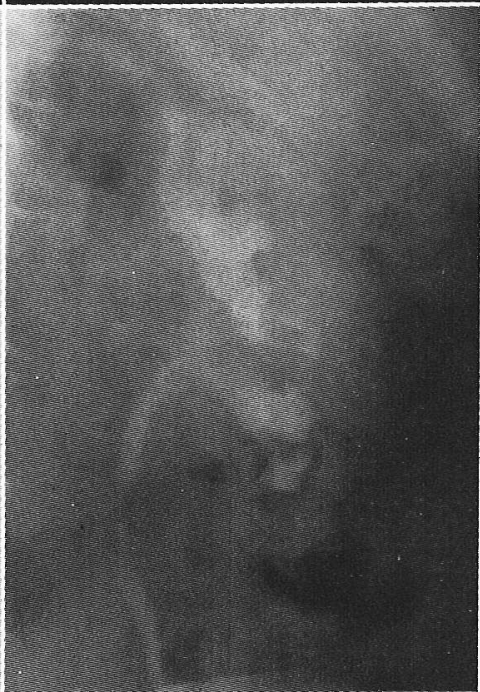

$\mathbf{E}$

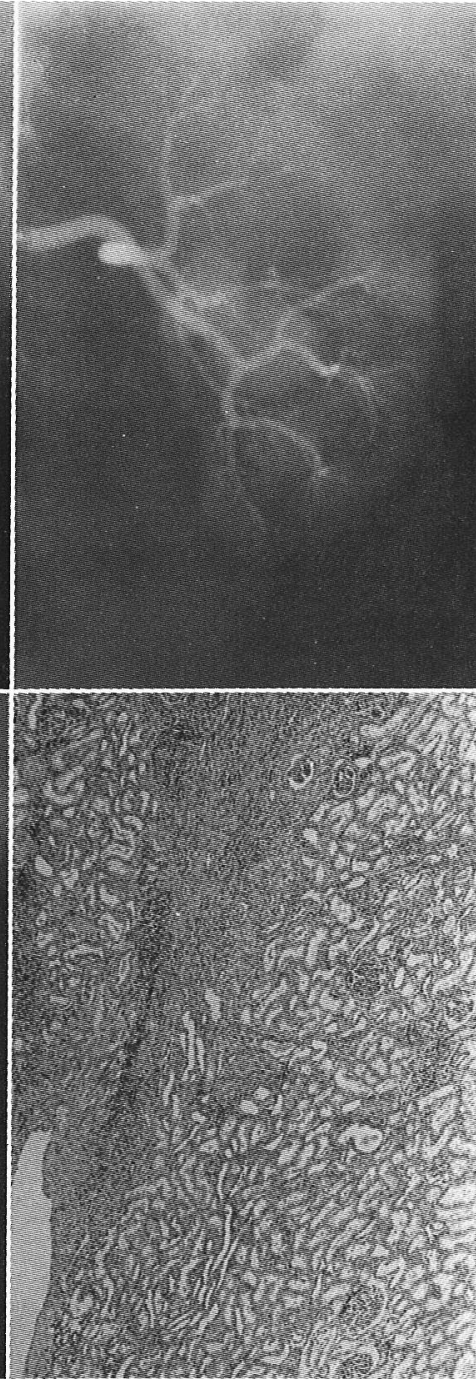

$\mathbf{F}$
6.4\%の減少を示す程度であり，縫合による腎主要血管 や実質への影響は軽微であつた。

術後の肉眼的血尿期間は平均すると 1 週間前後 ${ }^{8)}$ のこ とが多いが，今回の成績ではさらに短かく平均 $4.7 \pm 4.2$ 日であつた。しかし個々の症例では術後肉眼的血尿が全 くみられなかつたものから2週間まで持続したり術直後 に相当強い血尿をみたものなどかなりのバラつきがみら
れた。後者のような場合でも保存的に処置し術後管理上 特に問題は生じなかったが，このような差の生ずる原因 とその対策について検討した。

高齢者の老化が 進えだ腎や広範に炎症が 生じている 腎，広範な実質切開や長時間の腎血流遮断は組織の修復 に不利な条件と予測される。しかし具体的にはどの程度 の条件が術後肉眼的血尿期間を支配しているのかは不明 
第 7 図症例 $12 ， 34$ 藏，女子（術後血尿期間 2 日）
A：腎部単純撮影
B : 術前 IVP
$\mathrm{C}:$ 術前腎動脈撮影
$\mathrm{D}$ ：摘出結石
$\mathrm{E}:$ 術後 IVP
F：腎生検所見 $($ H.E. 染色 $\times 40)$

A

B
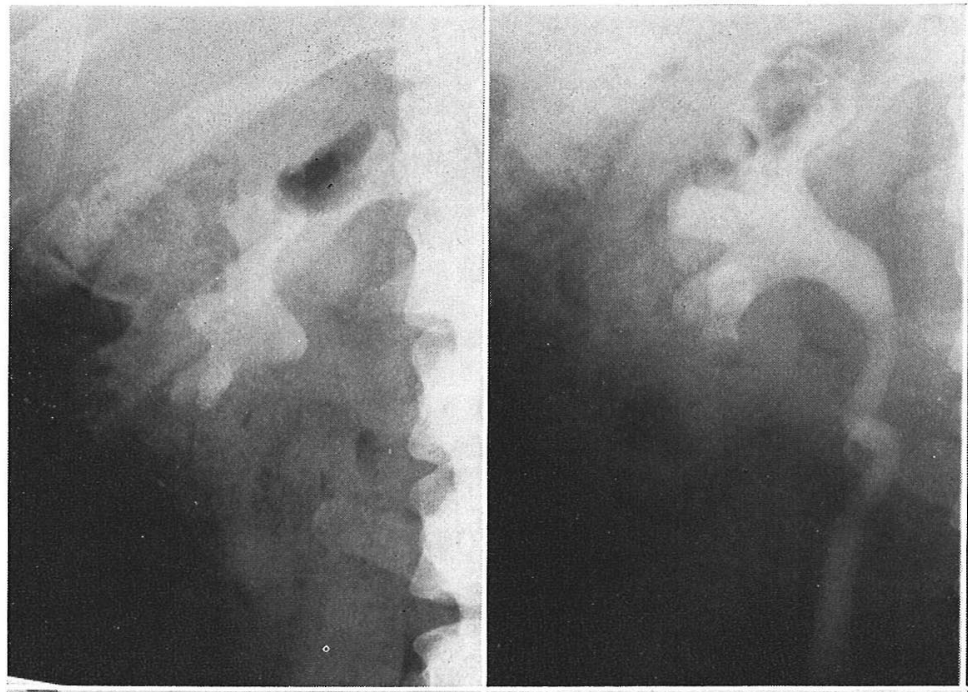

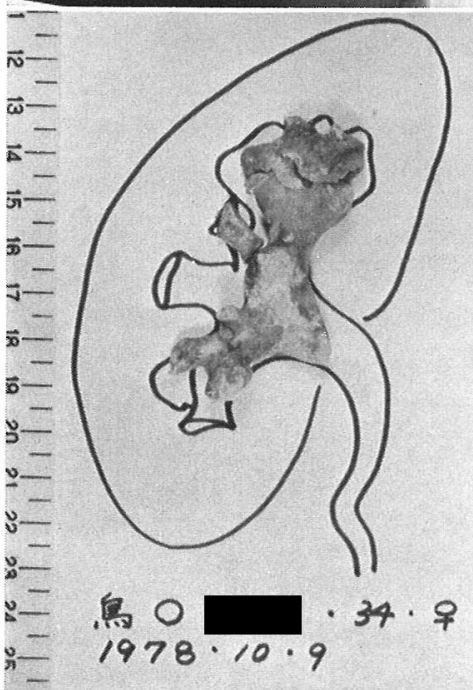

D

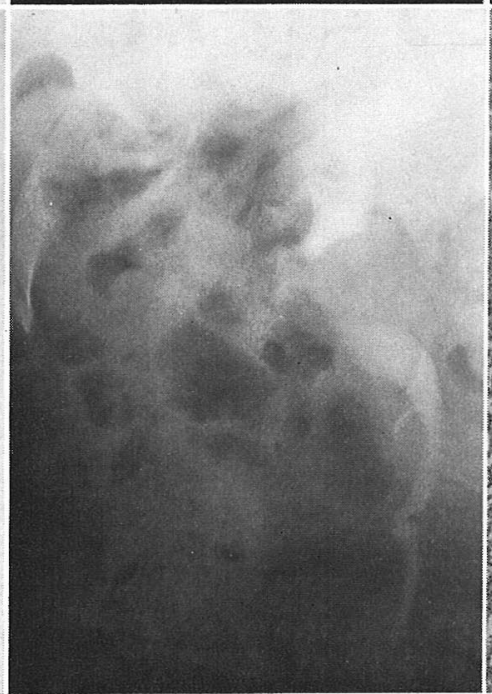

$\mathbf{E}$
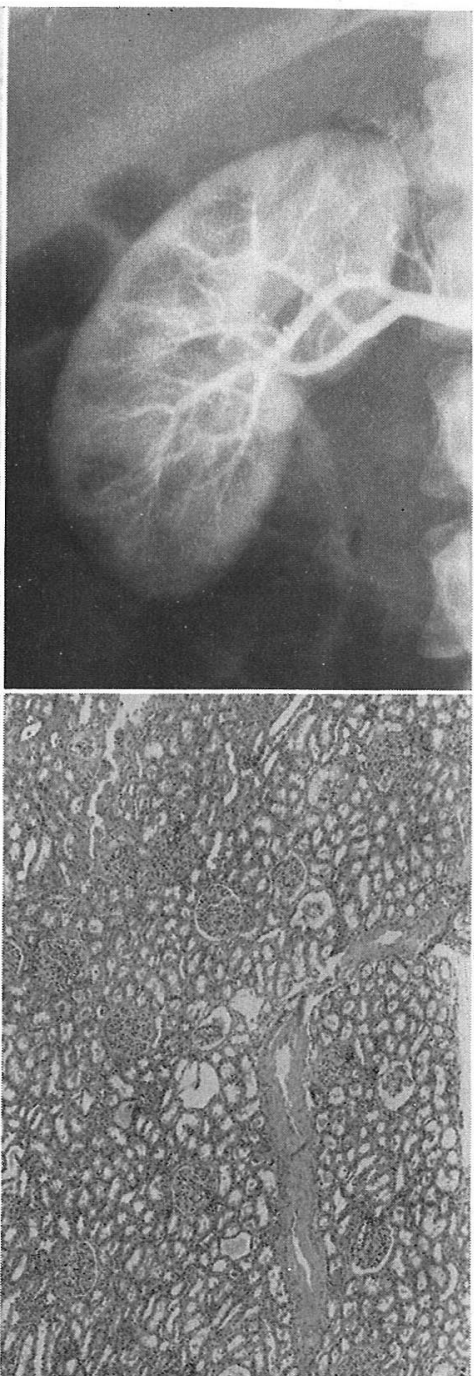

F
である.今回の成績は症例数が十分とは云兄ないが年 齢, 腎実質切開長, 腎血流遮断時間といら個々の事項と 術後肉眼的血尿期間の間に相関関係は認められなから た。

一方珊瑚状結石を有する腎では程度の差ことあれ腎盂 腎炎が必発するとされ9 〜2)，末た病変は進行性である と推測されている ${ }^{5)}$ （しかし慢性腎㙉腎炎の組織変化は
局在性のことが多く，術中の腎生検所見が腎組織の全て を代表しうるものではない，このような制約はあるが， 今回組織学的に腎盂腎炎を認めた群とそらでない群の血 尿期間を比較すると有意に前者のほうが長いという結果 が得られた。また自験例の症例11では組織像で慢性腎孟 腎炎を認めないにもかかわらず術後残結石が尿管に陥入 して高度の急性腎孟腎炎を発症し，平均をこえる肉眼的 
第 8 図

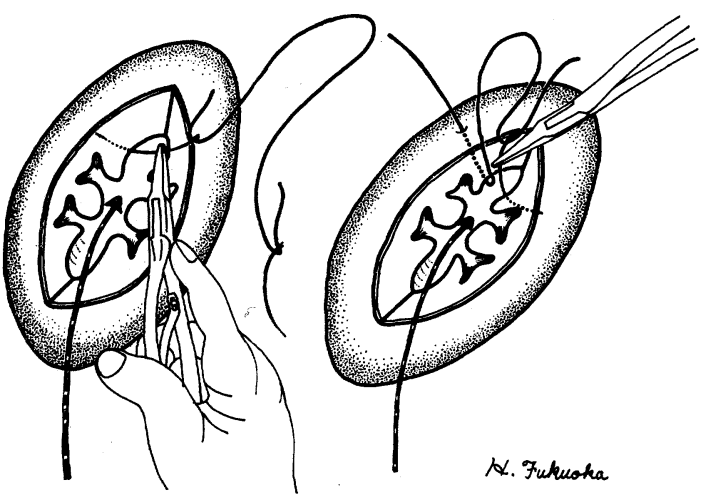

第 9 図

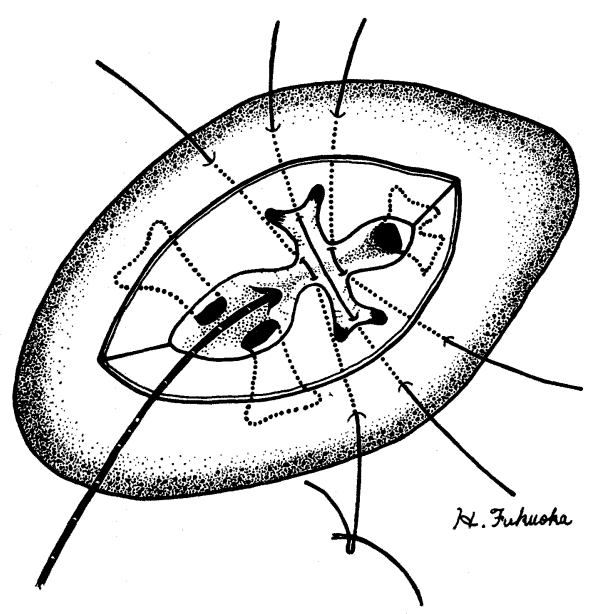

第10図 A：正しい縫合，B：不適切な縫合
A

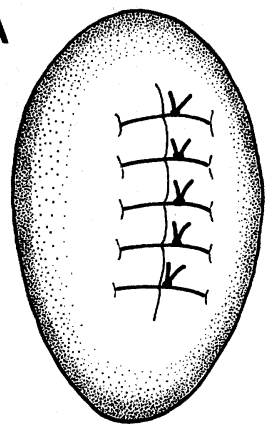

B

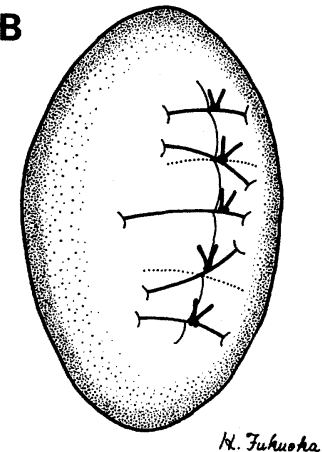

血尿期間が持続したが幸い結石が自排したため急性炎症 や血尿も消退した。 したがつて腎実質切開創の癒合や術 後血尿期間に炎症（既存たると続発たるとを問わず）が 密接な関係を有していることが示唆される. 自験例での
組織変化は間質の細胞浸潤や軽度の線維化などが主要な 所見であり糸球体の広範な障害を生じているものは少な く，慢性腎需腎炎はその病変の広がりが重要なのではな いかと推測される。

腎動脈像によれば腎雷像で判明するよりはるかに早期

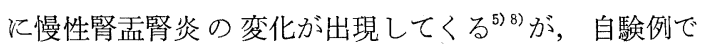
術前に腎動脈撮影を行なつた10例のうら組織像と動脈像 が一致したものは 6 例（このうち腎監炎が存在したも の 3 例, そうでないもの3 例), 動脈像の false positive 2 例, false negative 2 例であり, 術前に比較的早期の 慢性腎盂腎炎性変化を明らかにすることは必ずしも容易 ではない。

このような診断上の問題もあるが自験例の結果のごと $<2$ 週間程度の肉眼的血尿期間は許容範囲内であり, 臨 床的な観点からすれば十分な腎実質が残存していれば合 併する慢性腎需腎炎は腎切石術の手術適応の障害となら ない。

そのため広範な慢性炎症の存在が判明していたりその 疑があるような場合には，術直後の強い血尿や持続する 血尿を防止するため手術手技の面から特に注意を払わ称 ばならないと考える．基本的には腎創面の密着と腎而粘 膜の正確な寄せ合わせが重要である.結石と癒着したり 炎症のためもろくなつた腎需粘膜を保護し確実に糸を通 すため，縫合針は両切開面とも必ず腎盘から被膜にもか つて (内から外へ) 通すのがよい(第 8 図). 腎杯茎部が 切開されている場合は茎部の根元と腎杯先端に縫合部を 選ぶ(第 9 図).な扣このような部位が何力所かあると縫 合数は多少増加するが支障ない。また創面の密着のため 縫合糸は実質切開線と直角に交叉し, 実質刺出点は創面 の両側で対称となるよらたえず心がけることが大切であ る(第10図).

われわれはこのよらな注意を守ることにより，正確な 腎盂粘膜の寄せ合わせや創面の密着が得られ血尿を最少 限に扣さえらることを経験している。な縫合系の結禁 に際しては過剩にしめつけず，また結紮がゆるまないよ ら結杽部の根元を絹糸で結禁するなどのことは当然の前 提である。

\section{結 語}

1）腎実質一層縫合法（田口）による腎切石術を12症 例に実施し，術後肉眼的血尿期間とこれに影響を与える と思われた因子との関係を検討した。

2）術後肉眼的血尿期間は $0 \sim 14$ 日に分布し平均 4.7 土4.2日であつた。 
3）患者年齢，腎実質切開長，術中腎血流遮断時間と 術後肉眼的血尿期間の間に相関は認められなかつた.

4）術中腎生検所見 と術後肉眼的血尿期間 の 関係で は，慢性腎盂腎炎の所見を認める群の汪らがそうでない 群より血尿期間が長かつた。

5）慢性腎盂腎炎の合併は腎切石術の手術適応の障害 とはならないが，術後血尿を長びかせる因子の一つであ ることが示唆された。臨床的には術後血尿を最少限のる のとするため，腎実質一層縫合に際して創面の密着や腎 孟粘膜の正確な寄せ合わせを行なうよう注意しなければ ならない。

稿を終えるにあたり腎実質一層䋖合法を直接に御指導 いただいた国立相模原病院泌尿器科医長田口裕功博士に 厚く御礼申しあげます。また本論文の要旨は1979年 4 月 5 日東京都で開催された第67回日本泌尿器科学会総会で 報告した。

\section{文献}

1）田ロ裕功：サンゴ状結石の手術における腎実質 の縫合について, 安全な手術への道, 市川・福 田・榊原・村上・林・津山編，p. 258 , 金原出 版, 東京・京都, 1972 .

2）田口裕功，石塚栄一：サンゴ状結石およびそ れに類する腎結石の手術について，手術，26， 1088-1098, 1972.

3）田口裕功：サンゴ状結石の手術，腎切石術にお ける腎実質一層縫合，臨泌，30, 1027-1029, 1976.
4）福岡 洋：腎切石術における腎実質䋖合法の研 究，第 1 編，堅実質䋖合法の技術的变遷々腎穾 質一層縫合法の意義, 日泌尿会誌，68，440449, 1977.

5). 福岡 洋, 田口裕功, 山田哲夫 : 珊瑚状結石は どのような理由と方法で摘出されるのか, 両側 珊瑚状結石 の 1 例飞ついての検討, 日泌尿会 誌, 69, 232一238, 1978.

6) Taguchi, H., Fukuoka, H. and Yamada, T.: Nephrolithotomy by one layer interrupted parenchymal suture, Eur. Urol., in print.

7) 石塚栄一：サンゴ状結石拉よびそれに類する腎 結石の手術に関する 臨床的研究 (I)，日泌尿 会誌, 63, 809-832，1972.

8）福岡 洋: 腎切石術における腎実質縫合法の研 究，第 2 編，腎実質一層縫合法に扮汀る腎血管 変化の 臨床的検討, 目泌尿会誌， $68 ， 450-$ $470,1977$.

9) Allen, A.C.: The kidney, p. 519, Grune and Stratton, New York, 1962.

10）石塚栄一：サンゴ状結石およびそれに類する腎 結石の手術に関する臨床的研究（II），日泌尿 会誌, 63, 833-840, 1972 .

11）近藤捷嘉：抗生剂含有生食水飞上る持続的腎孟 潅流法に関する臨床的, 実験的研究; 特に腎册 瑚樹状結石症例飞対する腎切石術への適用につ いて，日泌尿会誌， 64，879-897，1973.

12）田口裕功, 石塚策一：レノグラムとその他の 分腎機能検查 および 腎組織像，日腎誌，17， 307-314, 1975.

（1979年 4 月14日受付） 